\title{
CdSe charge obtaining for single crystals growth in alkaline solutions
}

\author{
D.S.Sofronov ${ }^{1}$, P.V.Mormilo ${ }^{2}$, N.O.Kovalenko ${ }^{2,3}$, E.M.Sofronova $^{1}$, \\ P.V.Matejchenko ${ }^{3}$, E.Yu.Bryleva ${ }^{1}$, A.K.Kapustnik ${ }^{3}$, I.S.Terzin ${ }^{3}$
}

${ }^{1}$ Division of Functional Materials Chemistry, SSI "Institute for Single

Crystals", National Academy of Sciences of Ukraine,

60 Nauky Ave., 61001 Kharkiv, Ukraine

${ }^{2}$ V.Karazin Kharkiv National University, 4 Svobody Sq., 61022 Kharkiv, Ukraine

${ }^{3}$ Institute for Single Crystals, STC "Institute for Single Crystals", National Academy of Sciences of Ukraine, 60 Nauky Ave., 61001 Kharkiv, Ukraine

\section{Received September 4, 2017}

Cadmium selenide charge obtaining is proposed by interaction of cadmium nitrate with selenium in alkaline solution in the presence of hydrazine. It is shown that irrespective of alkali concentration and synthesis time, spherical particles (100-200 nm) of cadmium selenide with wurtzite structure are formed. Yield of the desired product increases with increasing the alkali concentration in the solution and the synthesis time and reaching a maximum of $97 \mathrm{wt}$ \%. The grown crystal CdSe by the Bridgman method from the synthesized charge is optically transparent, does not contain large macrodefects and visible block boundaries.

Keywords: CdSe, IR optics, Bridgman method, wet synthesis.

Предложено получение шихты селенида кадмия при взаимодействии нитрата кадмия с селеном в щелочном растворе в присутствии гидразина. Показано, что независимо от концентрации щелочи и времени синтеза происходит формирование сферических частиц (100-200 нм) селенида кадмия со структурой вюрцита. Выход целевого продукта возрастает при увеличении концентрации щелочи в растворе и времени синтеза, достигая максимального 97 масс.\%. Выращенный кристалл CdSe по методу Бриджмена из синтезированной шихты оптически прозрачен, не содержит крупных макродефектов и видимых границ блоков.

Отримання CdSe для вирощування монокристалів з лужних водних розчинів. Д.С.Софронов, П.В.Морлило, Н.О.Коваленко, О.М.Софронова, П.В.Матейченко, Е.Ю.Брилева, О.К.Капустник, С.З.Терзін.

Запропоновано отримання шихти селеніду кадмію при взаємодії нітрату кадмію 3 селеном у лужному розчині у присутності гідразину. Показано, що незалежно від концентрації лугу та часу синтезу відбувається формування сферичних частинок (100200 нм) селеніду кадмію зі структурою вюрциту. Вихід цільового продукту зростає при збільшенні концентрації лугу у розчині та часу синтезу, досягаючи 97 мас.\%. Отриманний кристал CdSe за методом Бріджмена із синтезованої шихти є оптично прозорий, не містить великих макродефектів та видимих кордонів блоків. 


\section{Introduction}

Materials based on cadmium selenide are widely used in production of tandem solar cells (as optical windows or base layers), photo and gas detectors, green light emitters, film transistors, electron-beam and optical pumping lasers, etc. [1-6]. In most cases, single crystals of cadmium selenide, obtained from vapor phase (PVT) or by more productive Bridgman method are used. The result of growing in mostly depends on purity, morphology and the stoichiometry of the initial raw materials and optimization of the synthesis process is an actual task.

For synthesis of metal chalcogenides the synthetic methods based on interaction of metal (oxide, carbonate or another metal salt) with selenium (hydrogen selenide) in solid [7, 8] or in gas [9] phases are used [10]. To obtain charge of $\mathrm{ZnSe}$ and MgSe, it has also been proposed to use microwave radiation for forcing the interaction of zinc or magnesium with selenium [11, 12]. However, such techniques require the special equipment. One of the simplest methods of the synthesis is sedimentation from aqueous solutions. In particular, it has been proposed to obtain a the charge of zinc selenide from alkaline solutions by interaction of zinc nitrate with selenium in the presence of hydrazine [13]. It is shown that zinc selenide, suitable for subsequent use as a charge can be obtained with a high practical yield (more than $95 \%$ ) from $5 \mathrm{M}$ alkali solution during $4 \mathrm{~h}$. This method can also be tested to obtain a charge of cadmium selenide, since cadmium and zinc have similar chemical properties.

The purpose of this work is testing of the synthesis of charge in alkaline solutions of CdSe, suitable for growing single crystals.

\section{Experimental}

$\mathrm{Cd}\left(\mathrm{NO}_{3}\right)_{2} \quad(\mathrm{hp})$, Se (99.9999 \%), $\mathrm{KOH}$ (hp) and hydrazine hydrate (hp) from "Reachim" manufacturer were used without further purification.

Cadmium selenide was prepared according to the following procedure: stoichiometric amounts of cadmium nitrate hexahydrate (weight $1.088 \mathrm{~g}$ in terms of cadmium oxide) and selenium (weight $1.118 \mathrm{~g}$ ) were charged to a round-bottomed flask of $250 \mathrm{ml}$ volume, $100 \mathrm{ml}$ of potassium hydroxide solution were added (the solution concentration was varied within 3-9 M) and mixed by magnetic stirrer for $30 \mathrm{~min}$. Then $0.5 \mathrm{ml}$ of hydrazine hydrate was added, the solution was heated to boiling with constant stirring and boiled for 2-12 hours. At the end, the precipitate was separated in a centrifuge and washed several times with distilled water, and then dried at room temperature for $48 \mathrm{~h}$.

IR spectra were obtained using Fourier spectrophotometer SPECTRUM ONE (PerkinElmer) with potassium bromide tablets. X-ray diffraction patterns (XRD) of the samples were measured by Siemens D500 diffractometer using $\mathrm{Cu}-\mathrm{K} \alpha$ radiation $(\lambda=$ $1.5418 \AA$ ) at $40 \mathrm{kV}$ and $100 \mathrm{~mA}$. The scanning range was $10<2 \theta<90^{\circ}$ and the exposure - 10 seconds per point. Morphology and microstructure were analyzed using a scanning electron microscope DSM-6390LV (SEM). Concentration of metals in the samples was determined by inductively coupled plasma atomic emission spectrometer TRACE SCAN Advantage from Thermo Jarrell Ash (USA).

\section{Results and discussion}

Formation of cadmium selenide in solution occurs according to the following scheme:

$$
\begin{gathered}
3 \mathrm{Se}+6 \mathrm{OH}^{-}=2 \mathrm{Se}^{2-}+\mathrm{SeO}_{3}^{2-}+3 \mathrm{H}_{2} \mathrm{O}, \\
\left.\mathrm{Cd}^{2+}+4 \mathrm{OH}^{-}=\left[\mathrm{Cd}(\mathrm{OH})_{4}\right]^{2-}\right], \\
2 \mathrm{SeO}_{3}^{2-}+3 \mathrm{~N}_{2} \mathrm{H}_{4}=2 \mathrm{Se}^{2-} \downarrow+3 \mathrm{~N}_{2}+6 \mathrm{H}_{2} \mathrm{O}, \\
{\left[\mathrm{Cd}(\mathrm{OH})_{4}\right]^{2-}+\mathrm{Se}^{2-}=\mathrm{CdSe} \downarrow+4 \mathrm{OH}^{-}}
\end{gathered}
$$

In alkaline solution, selenium, when heated, is disproportionated by reaction 1 to form $\mathrm{Se}^{2-}$ and selenite $\mathrm{SeO}_{3}{ }^{2-}$ ions, and cadmium ions are present in the solution as $\left[\mathrm{Cd}(\mathrm{OH})_{4}\right]^{2-}$ complex formed by reaction 2 . As a result of the interaction of the $\left[\mathrm{Cd}(\mathrm{OH})_{4}\right]^{2-}$ ion with $\mathrm{Se}^{2-}$, cadmium selenide is formed by reaction 4 . To increase the formation of selenide ions in solution, the selenite ions are reduced to $\mathrm{Se}^{2-}$ by hydrazine (reaction 3 ).

Since diffractograms of the powders were identical, only diffraction pattern of cadmium selenide powder obtained from $3 \mathrm{M}$ $\mathrm{KOH}$ solution during $6 \mathrm{~h}$ treatment is shown in Fig. 1. The diffractogram shows only diffraction reflections typical of cadmium selenide with the wurtzite structure.

Dependence of the cadmium selenide yield on the synthesis conditions is shown in Fig. 2. Increasing the concentration of alkali and increasing the duration of the 


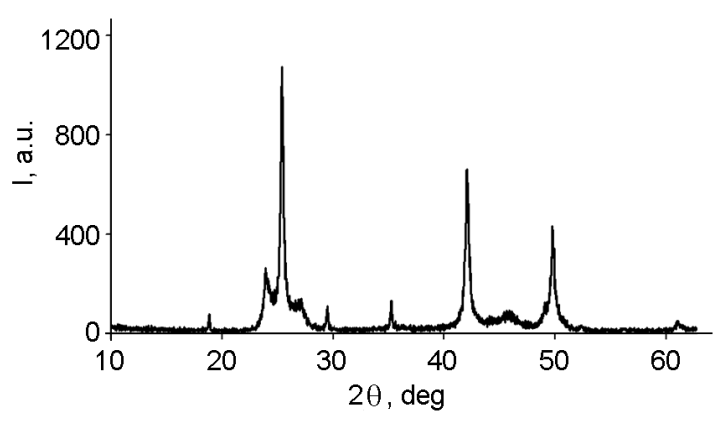

Fig. 1. Diffractogram of cadmium selenide powder obtained from $3 \mathrm{M} \mathrm{KOH}$ for $6 \mathrm{~h}$.

synthesis leads to increase in the yield of cadmium selenide. The maximum yield is observed when the synthesis is carried out in $5 \mathrm{M}$ solution of potassium hydroxide for 4-6 h. With increase in the synthesis time to $24 \mathrm{~h}$, the practical yield of the product was $97 \%$ by weight.

In the synthesis process in alkaline solution the cadmium selenide can be contaminated with oxygen-containing impurities (selenites and hydroxides) formed as results of reactions 1 and 2 . In addition, the formation of carbonates is possible due to carbonization of the alkaline solution. In order to control the impurity composition for oxygen-containing impurities, IR spectrometry was used. As is known, cadmium selenide in the IR region is transparent, and oxygencontaining impurities (carbonates, hydroxides, selenides) have corresponding characteristic absorption bands. In IR spectra (Fig. 3 ) of the samples synthesized from 1 and $3 \mathrm{M}$ solutions of $\mathrm{KOH}$, a broad absorption band is observed in the region of $1350-1500 \mathrm{~cm}^{-1}$, due to presence of carbonate ions. At the same time, its intensity decreases with an increase in the concentration of alkali in the solution. For the samples obtained from the $5 \mathrm{M}$ solution of $\mathrm{KOH}$, the absorption bands are practically not observed.

Micrographs of synthesized particles are shown in Fig 4. Regardless of the time of precipitation and the concentration of alkali, formation of spherical particles with a size of 100-200 nm occurs. Based on the IR spectrometric control data, the following

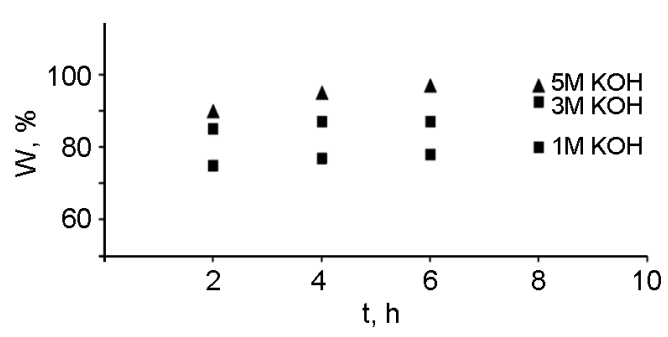

Fig. 2. Dependences of the yield of cadmium selenide on synthesis conditions.

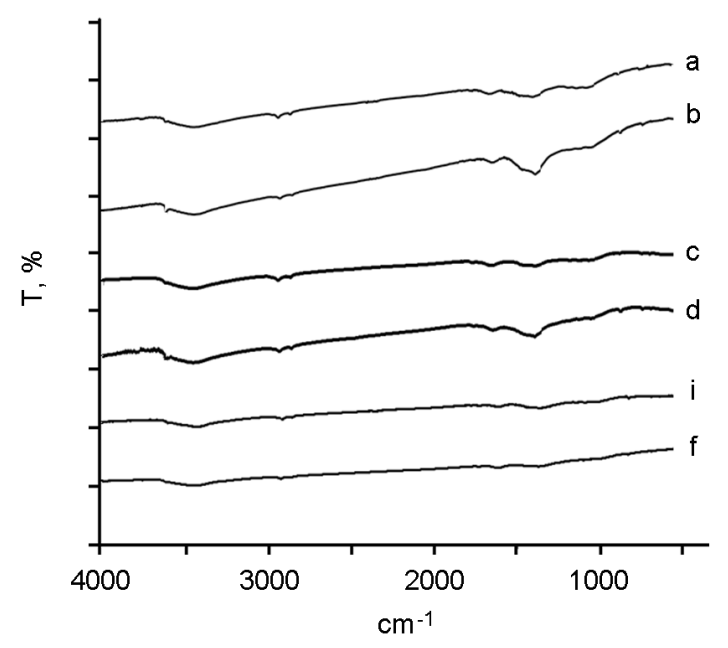

Fig. 3. IR spectra of powders obtained from 1 $(\mathrm{a}, \mathrm{b}), 3(\mathrm{c}, \mathrm{d})$ and $5 \mathrm{M}(\mathrm{i}, \mathrm{f}) \mathrm{KOH}$ solution for 4 (a, c, i) and $8 \mathrm{~h}(\mathrm{~b}, \mathrm{~d}, \mathrm{f})$.

parameters for the synthesis of cadmium selenide charge can be recommended: $5 \mathrm{M}$ of alkali concentration in the solution and synthesis time of $6-8 \mathrm{~h}$. Under these conditions, the maximum yield of the desired product is achieved and no formation of oxygen-containing impurities is observed.

As a result of synthesis, $240 \mathrm{~g}$ of cadmium selenide charge from $5 \mathrm{M} \mathrm{KOH}$ solution were obtained for $6 \mathrm{~h}$. The Table shows the results of determining the content of metals in the sample. According to the results of chemical analysis, the content of metal impurities is in the range of $10^{-5}-10^{-4}$ wt. $\%$.

For obtaining the single crystal CdSe the growth equipment developed and manufac-

Table. Results of determination of the metal content in standard charge of cadmium selenide and in sample synthesized from $5 \mathrm{M} \mathrm{KOH}$ solution for $8 \mathrm{~h}$

\begin{tabular}{|c|c|c|c|c|c|c|c|c|c|c|c|}
\hline \multirow[t]{2}{*}{ Sample } & \multicolumn{11}{|c|}{ Concentration, wt. $\%$} \\
\hline & $\mathrm{Fe}$ & $\mathrm{Si}$ & $\mathrm{Mg}$ & $\mathrm{Ni}$ & Sn & $\mathrm{Pb}$ & $\mathrm{Cr}$ & $\mathrm{Al}$ & Mo & $\mathrm{Cu}$ & $\mathrm{Mn}$ \\
\hline Standard & $1 \cdot 10^{-6}$ & - & $2 \cdot 10^{-5}$ & $5 \cdot 10^{-5}$ & $1 \cdot 10^{-4}$ & $4 \cdot 10^{-4}$ & $1 \cdot 10^{-4}$ & $110^{-4}$ & $5 \cdot 10^{-5}$ & $2 \cdot 10^{-5}$ & $2 \cdot 10^{-5}$ \\
\hline $\begin{array}{c}\text { Synthesis of } \\
5 \mathrm{M} \mathrm{KOH}\end{array}$ & $3 \cdot 10^{-5}$ & $1 \cdot 10^{-3}$ & $2 \cdot 10^{-4}$ & $2 \cdot 10^{-5}$ & $2 \cdot 10^{-5}$ & $8 \cdot 10^{-4}$ & $1 \cdot 10^{-5}$ & $2 \cdot 10^{-4}$ & $5 \cdot 10^{-5}$ & $5 \cdot 10^{-5}$ & $3 \cdot 10^{-5}$ \\
\hline
\end{tabular}



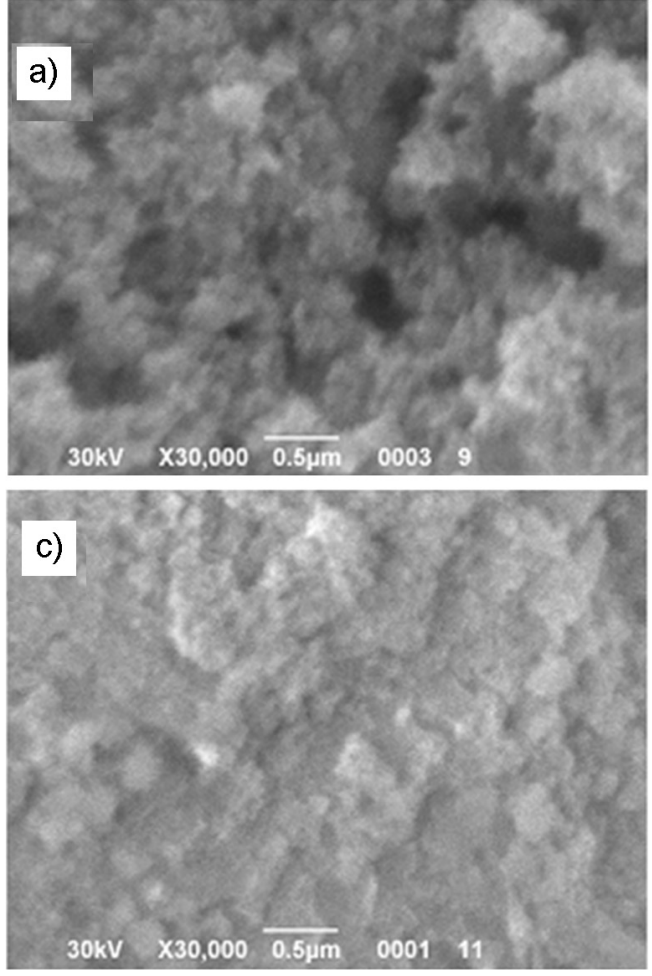
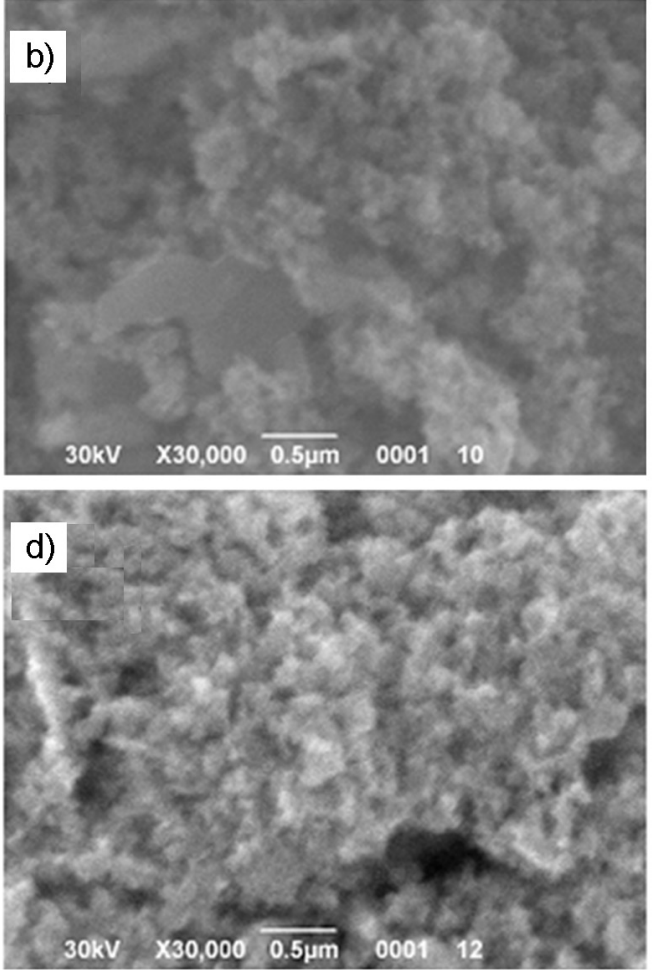

Fig. 4. Photomicrographs of CdSe particles obtained from alkaline solutions at alkali concentration $(M)$ and deposition time $(h)$, respectively: $\mathrm{a}-1$ and $4 ; \mathrm{b}-3$ and $4 ; \mathrm{c}-3$ and 8 ; $\mathrm{d}-5$ and 8 .
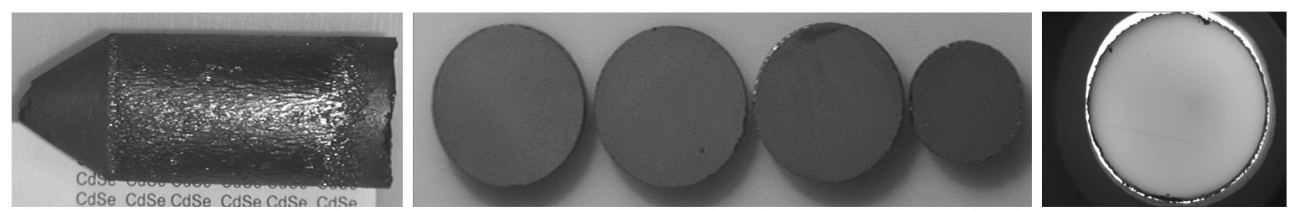

Fig. 5. Photo of crystalline ingot, cut and polished plates and IR photo of the puck "on the skylight".

tured at the Institute for Single Crystals of the NAS of Ukraine was used. The growing process was carried out in a graphite crucible of PGM-7 brand by the Bridgman method under excessive pressure of inert gas (argon). Temperature gradient in the growth zone was $\sim 30^{\circ} \mathrm{C} / \mathrm{cm}$, the crucible pulling speed was $1.8 \mathrm{~mm} / \mathrm{h}$, which corresponded to the conditions for growing crystals from commercial raw materials. As a result, a crystalline ingot was obtained, photograph of which is shown in Fig. 5. The grown ingot is transparent in near and middle IR spectral range, does not contains large macrodefects and visible block boundaries.

Fig. 6 shows the spectrum of optical transmission in the IR range. In the spectrum of the crystal grown from the synthesized charge (Fig. 6 curve 1), a monotonic drop in transmittance is observed in the re-

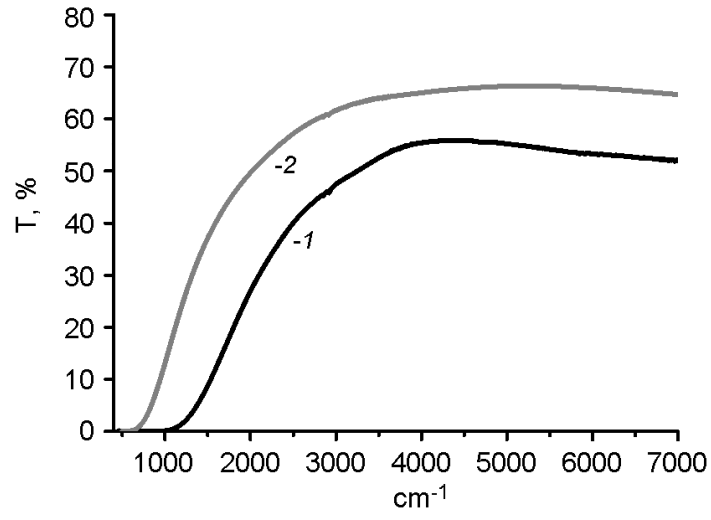

Fig. 6. Spectra of optical transmission of the obtained crystal sample of CdSe (1) and the crystal from commercial raw materials (2).

gion of 3-9 $\mu \mathrm{m}$. In addition, in comparison with the transmittance spectrum of the crystal grown from the commercial raw ma- 
terials (Fig. 6 curve 2), the grown crystal of synthesized cadmium selenide has a lower transmission, which is typical for crystals with low ohmic resistance of $\sim 10^{6} \mathrm{Ohm} \cdot \mathrm{cm}$. For increasing the electrical resistance and optical transmission the special doping can be used.

Thus, CdSe crystal grown from the charge synthesized in this work and needed doping is suitable for manufacturing the optical elements of infrared optics and active elements of mid-IR lasers.

\section{Conclusions}

Method of obtaining of cadmium selenide charge is proposed by interaction of cadmium nitrate with selenium in alkaline solution in the presence of hydrazine. It is established that irrespective of the synthesis conditions (alkali concentration and deposition time), spherical particles $(100-200 \mathrm{~nm})$ of cadmium selenide with wurtzite structure are formed. The yield of the desired product increases with increase in the concentration of alkali in the solution and the synthesis time. The maximum yield ( 97 wt. $\%$ ) is obtained by performing the synthesis from $5 \mathrm{M} \mathrm{KOH}$ solution for 6-8 h. The cadmium selenide powder obtained by the developed method can be used to grow the single crystals using the Bridgman method.

\section{References}

1. P.Michler, M.Vehse, J.Gutowski et al., Phys. Rev. B, 58, 2055 (1998).

2. Luminescence of Solids, ed. by D.R.Vij, Plenum Press, New York (1998).

3. V.K.Komar, V.M.Puzikov. Scintillates on the Basis of $A^{2} B^{6}$ Compounds: Obtaining, Properties and Features of Application, Institute for Single Crystals, Kharkov (2007).

4. J.McKey, K.L. Schepler, G.C.Catella, Opt. Lett., 24, 1575 (1999).

5. S.Velumani, X.Mathew, J.Sebastian et al., J. Mater. Sci. Lett., 22, 25 (2003).

6. S.A.Mahmoud, A.Ashour, E.A.Badawi, Appl. Surf. Sci., 253, 2969 (2006).

7. D.M.Chizov, V.P.Schaslivij, Selen and Selenides, Nauka, (1964).

8. V.A.Obolonchik, Selenides, Metallurgiya (1972).

9. A.Colli, S.Hofmann, A.C.Ferrari et al., Nanotechnology, 16, 139 (2006).

10. X.T.Zhang, Z.Liu, K.M.Ip et al., J.Appl. Phys., 95, 5752 (2004).

11. D.S.Sofronov, E.M.Sofronova, V.V.Starikov et al., J. Mater. Engin. Perform., 22, 1637 (2013).

12. D.S.Sofronov, Y.A.Zagoruiko, N.O.Kovalenko et al., Mater. Manufact. Proc., 28, 944 (2013). 